UDC 547:724

\author{
A.B. Surovtsev ${ }^{a}$, I.A. Mandzyuk ${ }^{b}$, D.O. Chervakov ${ }^{c}$, M.F. Seferova ${ }^{d}$, O.V. Chervakov ${ }^{c}$
}

\title{
STUDY OF THE RHEOLOGICAL PROPERTIES OF THE HIGHLY-FILLED PASTE- LIKE FUEL COMPOSITION BASED ON OLIGOMERIC RUBBER AND DISPERSED FILLERS
}

\author{
a Oles Honchar Dnipro National University, Dnipro, Ukraine \\ ${ }^{\text {b }}$ Khmelnytskyi National University, Khmelnytskyi, Ukraine \\ c Ukrainian State University of Chemical Technology, Dnipro, Ukraine \\ ${ }^{d}$ Dnipro State Medical University, Dnipro, Ukraine
}

\begin{abstract}
We present the results of creation of paste-like fuel compositions with a high degree of filling (up to $90 \mathrm{wt} . \%$ ) and investigation of their rheological properties. The developed composition contained the following components: a polymer matrix (type SNBR-N butadiene rubber) and a mixture of inorganic fillers (preliminarily surface-modified highly disperse potassium chloride, that was microencapsulated by using oligomeric products of polyehtyleneterepthalate glycerolize, and highly dispersed aluminum powder. A surfaceactive compound (oligomeric polioxypropylene glycol) and plasticizers of different natures were used as additional components, which were introduced in order to increase the degree of filling of the resulting paste-like compositions while maintaining a low level of their viscosity. The dynamic viscosity of the compositions was evaluated in the range of the shear stresses of 1 to $30 \mathrm{kPa}$ and the temperatures of 293 to $323 \mathrm{~K}$ by using a rotary viscometer (cone-plane system). The viscosity of the composition which is a mixture of saturated and unsaturated methyl ester fatty acids at the maximum degree of filling (90 wt.\%) was at the level of viscosity of the individual binder.
\end{abstract}

Keywords: highly filled paste-like fuel composition, rheological properties, dispersed filler, oligomeric rubber, surface modification, surface-active compound, plasticizer.

DOI: $10.32434 / 0321-4095-2021-138-5-111-117$

\section{Introduction}

In rocket engines along with the use of solid and liquid rocket fuels, the most perspective and rationale is a change to paste-like systems. The use of paste-like fuels can provide a multi-start/stop of rocket engine also within a drag changing and maneuvering at fly trajectories [1]. In comparison with liquid and solid fuels, paste-like fuel is safer [2] and easier in production [3]. In addition, when using a paste-like fuel composition, it is possible to modify repeatedly (up to 80 times) and purposefully regulate the energy parameters of the fuel [4], which can be provided by the non-linear law of fuel consumption depending on pressure changing along with anomalous flowability of paste-like composition.

The main requirements to paste-like fuels are established in works $[3,5]$. According to those requirements, the main attention should be focused on the following issues:
- achievement of the maximum degree of fuel composition filling (up to $90 \mathrm{wt} . \%$ ) with providing high energy parameters;

- obtaining a homogenous consistency of fuel composition which is capable of flowing under load;

- obtaining compositions with high density and composition stability in the temperature range of 263 to $325 \mathrm{~K}$ as well as sedimentation stability during storage and transportation;

- obtaining fuel compositions with a low sensibility to impact or kinetic forces.

Usually, paste-like fuels include fuel binder and oxidizer, which are the main components. Due to the high oxygen balance and sufficient physicochemical stability, the most commonly used oxidizer is the highly dispersed ammonium perchlorate. It should be noted that this oxidizer is environmentally dangerous because of its ability to release large amount of hydrogen chloride during

(C) A.B. Surovtsev, I.A. Mandzyuk, D.O. Chervakov, M.F. Seferova, O.V. Chervakov, 2021

Study of the rheological properties of the highly-filled paste-like fuel composition based on oligomeric rubber and dispersed fillers 
The PGO sample characteristics

\begin{tabular}{c|c|c}
\hline Sample designation & The initial components ratio, wt. parts & Appearance and viscosity at 323 K \\
\hline PGO-4 & PET/PEG-400 $=50 / 50$ & White paste-like compound, 18 Pa·s \\
\hline PGO-5 & PET/PEG-400 $=60 / 40$ & Light-yellow paste-like compound, 20 $\mathrm{Pa} \cdot \mathrm{s}$ \\
\hline PGO-6 & PEG-400/glycerol=40/60 & White viscous liquid, 9 Pa·s \\
\hline PGO-7 & PEG-400/glycerol=80/20 & White viscous liquid, 12 Pa·s \\
\hline
\end{tabular}

fuel combustion.

Uncured low-molecular or high-molecular plasticized polymers are used as fuel-binders. In order to increase the energy characteristics, an additional filler is introduced into the paste-like fuel: a metal in a highly dispersed form (mainly aluminium) or other solid-phase powdery or liquid substances with a high formation enthalpy.

Highly-filled paste-like systems must possess the properties of a non-Newtonian liquid capable of flowing under load. They may therefore include additives that provide the required rheological characteristics, a certain burning rate, etc. [5].

Notwithstanding the existing scientific approaches to the creation of systems based on polymer matrix filled with dispersing particles [6,7], the production of paste-like fuel compositions and the assessment of their ability to flow under load should be experimentally resolved. This can be achieved by the selection of qualitatively new raw materials of different chemical composition, size and shape of filling particles, their surface conditions, etc. [8]. This study is aimed at obtaining highlyfilled paste-like fuel model systems and evaluating their rheological properties in a temperature range specified by the operating conditions.

\section{Experimental}

\section{Materials}

Previously described formulations [9] based on fuel-binder (oligomer rubber), highly dispersed fillers $\mathrm{KCl}$ (potassium chloride and powdered aluminium), plasticizer and surfactants were used in order to prepare paste-like fuel compositions.

A non-functional cis-butadiene low molecular SNBR-N type rubber was used as a combustible polymer (oligomeric rubber), it is a product of butadiene polymerization with nickel salts and aluminum-organic compounds catalysts mixture. The oligomeric rubber has a molecular weight of 2500 and shows the presence of $70-80 \%$ cis- 1,4 segments in the polybutadiene chain [10].

A surface-modified highly dispersed inert component, potassium chloride, which simulates a real oxidant in fuel compositions (ammonium perchlorate), was used as the main filler.
A highly dispersed aluminum (ASD-4) with average particle size of $12.4 \mu \mathrm{m}$, which was introduced as a high-energy additive into the fuel compositions, was used as additional filler.

Powdered $\mathrm{KCl}$ surface modification was carried out by using the products of polyethyleneterephthalate (PET) alcoholysis (PGO) [12], their speciation and properties are shown in Table 1.

High-efficient [11] oligomeric polioxypropylene glycol (POPG) was used as a surface-active compound with the following chemical formula $\mathrm{HO}\left[\mathrm{CH}_{2}\left(\mathrm{CH}_{3}\right) \mathrm{CHO}\right]_{n} \mathrm{H}$ (where $\mathrm{n}=17.2$ and molecular weight is 1000), a transparent liquid without color and odor.

Transformer oil, chemically similar to butadiene rubber, the above mentioned additives PGO-6 and PGO-7 (Table 1) and synthetic products of methanolysis of chicken fat, bioplasticizer BIO-5A (samples 1 and 2), that are the mixtures of methyl esters of fatty and unsaturated acids, were used as plasticizers in the composition of the binder for comparison with the previously considered dioctyl phthalate [9].

Bio-plasticizer BIO-5A is a mixture of highpurified methyl esters of fatty acids and unsaturated acids of chicken fat (FAME) in the production of which substitution methanol is removed and purified on Amberloost BD 10 DRY [13].

BIO-5A found a use as coating, polymer and rubber modification additive. Basic physicochemical properties of BIO-5A are shown in Table 2. The chemical nature and content of methyl esters of fatty and unsaturated acids in it are given in Table 3.

Table 2

The characteristics of BIO-5A plasticizer [14]

\begin{tabular}{l|c}
\hline \multicolumn{1}{c|}{ Characteristic } & Value \\
\hline Density, $\mathrm{kg} \mathrm{m}^{-3}$ & 868.0 \\
\hline Refractive index at $20^{\circ} \mathrm{C}$ & 1.446 \\
\hline Dynamic viscosity, $\mathrm{mPa} \cdot \mathrm{s}$ & 60 \\
\hline Mass fraction of soap, $\%$ & 0.1 \\
\hline Methanol content, wt. $\%$ & 0.02 \\
\hline Iodine number, $\mathrm{g} \mathrm{I}_{2}$ per $100 \mathrm{~g}$ & 92.1 \\
\hline Acidic number, $\mathrm{mg} \mathrm{KOH} \mathrm{per} \mathrm{g}$ & 0.3 \\
\hline Appearance & transparent yellow liquid \\
\hline
\end{tabular}


Chemical nature and FAME components content [14]

\begin{tabular}{l|c|c|c|c|c}
\hline $\begin{array}{c}\text { Fatty acid } \\
\text { type }\end{array}$ & \multirow{2}{*}{$\begin{array}{c}\text { Count in FAME } \\
\text { mixture, wt.\% }\end{array}$} & \multicolumn{2}{|c|}{ Number of } & Melting point, & $\begin{array}{c}\text { Boiling point, } \\
{ }^{0} \mathrm{C}\end{array}$ \\
\hline Lauric & 0.1 & 12 & 0 & 4.3 & 298.9 \\
\hline Muristic & 0.9 & 14 & 0 & 18.1 & 248.0 \\
\hline Palmitic & 21.6 & 16 & 0 & 28.5 & 267.0 \\
\hline Stearic & 6.0 & 18 & 0 & 37.7 & 376.1 \\
\hline Palmitoleic & 5.7 & 16 & 1 & -34.1 & 229.0 \\
\hline Oleic & 37.3 & 18 & 1 & -20.2 & 226.0 \\
\hline Gadoleic & 1.1 & 20 & 1 & -7.8 & 246.1 \\
\hline Linoleic & 19.5 & 18 & 2 & -43.0 & 229.0 \\
\hline Linolenic & 1.0 & 18 & 3 & 11.0 & 249.0 \\
\hline Arachidonic & 0.1 & 20 & 4 & -49.5 & 220.0 \\
\hline Others & $\sim 4$ & & & & \\
\hline
\end{tabular}

\section{Preparation of paste-like compositions}

The components of the compositions, with the exception of the main filler $\mathrm{KCl}$, do not require special preparation.

Preparation of the main filler $\mathrm{KCl}$ was done in several stages: crushing by ball mill, separation on screen plates with defined cell size, drying to stable mass at $393 \mathrm{~K}$, cooling and packing to vacuumsealed storage units (to minimize contact with air moisture). $\mathrm{KCl}$ used in this composition contained the fractions of less than $45 \mu \mathrm{m}$ and in the range of 45 to $63 \mu \mathrm{m}$ in the ratio of $1: 1$.

To perform surface modification of $\mathrm{KCl}$, a method similar to that used in work [9] was chosen: the part of PGO (PET alcoholysis products) in the quantity of $2 \mathrm{wt} . \%$ (with respect to the filler weight) was solved in acetone and mixed with the crushed $\mathrm{KCl}$ to obtain $10 \mathrm{wt} \%$ solution. The prepared compound was kept under intensive mixing at $333 \mathrm{~K}$ in the flask with a direct condenser for acetone removal. After modification, the prepared filler was dried to a stable weight at $293 \mathrm{~K}$ for full acetone removal. The dry mixture was separated to $63 \mu \mathrm{m}$ particle size to separate and remove aggregated particles.

The surface modification was evaluated based on the solubility of the sample in water. Unlike the initial $\mathrm{KCl}$, the modified filler is practically insoluble in water, which confirms the coating of the filler particles with a PGO modifier, i.e. the encapsulation effect of these particles.

Preparations of a model paste-like composition based on surface-modified $\mathrm{KCl}$ were done in a water bath $(323 \mathrm{~K})$ by the mixing of calculated amounts of SNBR-N, surface-active compounds and the dispersed fillers $(\mathrm{KCl}$ and $\mathrm{Al})$. Distribution of all components over the volume of the composition was ensured by intense mixing by electric paddle type agitator for 20 minutes, followed by the visual assessment of the mixture quality.

The prepared composition was condensed in the vacuum chamber (residual pressure of $50 \mathrm{~mm}$ of $\mathrm{Hg}$ and temperature of $323 \mathrm{~K}$ ) for 30 minutes for air removal that appeared during the previous process.

The rheological properties (dynamic viscosity) of the paste-like compositions were determined by means of a cone-plane type rotary viscometer Reotest- 2 in the range of shear stress of 1 to $30 \mathrm{kPa}$ and the temperatures of 293 to $323 \mathrm{~K}$. The measurement error was not more than $1 \%$.

\section{Results and discussion}

Highly filled paste-like compositions containing only $13-15 \mathrm{wt} . \%$ of the binder (SNBR-N), according to earlier investigations [9], are on the verge of loss of integrity and fluidity, and the application of additional plasticizer improves the properties of the system.

An influence of plasticizers of different nature is considered to increase the degree of filling of such compositions while maintaining their stability and ability to flow. The total degree of filling was 85 wt. $\%$ (70 wt. $\%$ of surface-modified $\mathrm{KCl}$ and 15 wt.\% of $\mathrm{Al}$ ) with saving equal sums of SNBR-N, surface-active compounds, oligomeric surface modification additives and plasticizer. Experimental results are shown in Fig. 1.

With a total binder phase of $13 \mathrm{wt} \%$, positive results are obtained as there is a significant decrease in viscosity as compared with the dioctyl phthalate plasticizer, for which the value is $30 \mathrm{~Pa} \cdot \mathrm{s}$. The best results were observed by using a $\mathrm{BIO}-5 \mathrm{~A}$ plasticizer. The viscosity of the compositions containing the said plasticizer in the studied shear stress range is about $10 \mathrm{~Pa} \cdot \mathrm{s}$. 


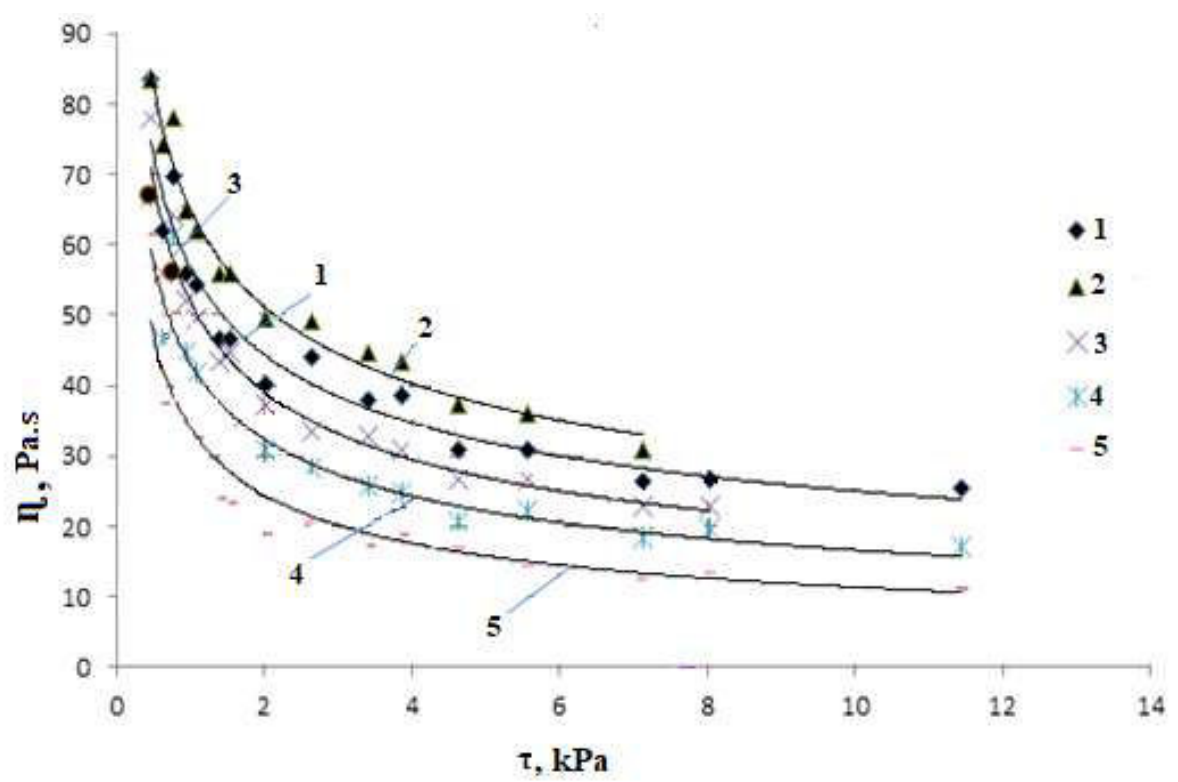

Fig. 1. The viscosity $(323 \mathrm{~K})$ of paste-like compositions with $85 \mathrm{wt} . \%$ feeling degree $(70 \mathrm{wt} . \%$ of $\mathrm{KCl}$ modified by $2 \mathrm{wt} . \%$ PGO-4+15 wt.\% of $\mathrm{Al}$ ) based on SNBR-N with $0.5 \mathrm{wt} . \%$ surface-active compound (POPG) and 3 wt. $\%$ of plasticizers: 1 - PGO-7, 2 - without plasticizers, 3 - PGO-6, 4 - transformer oil, and 5 - BIO-5A

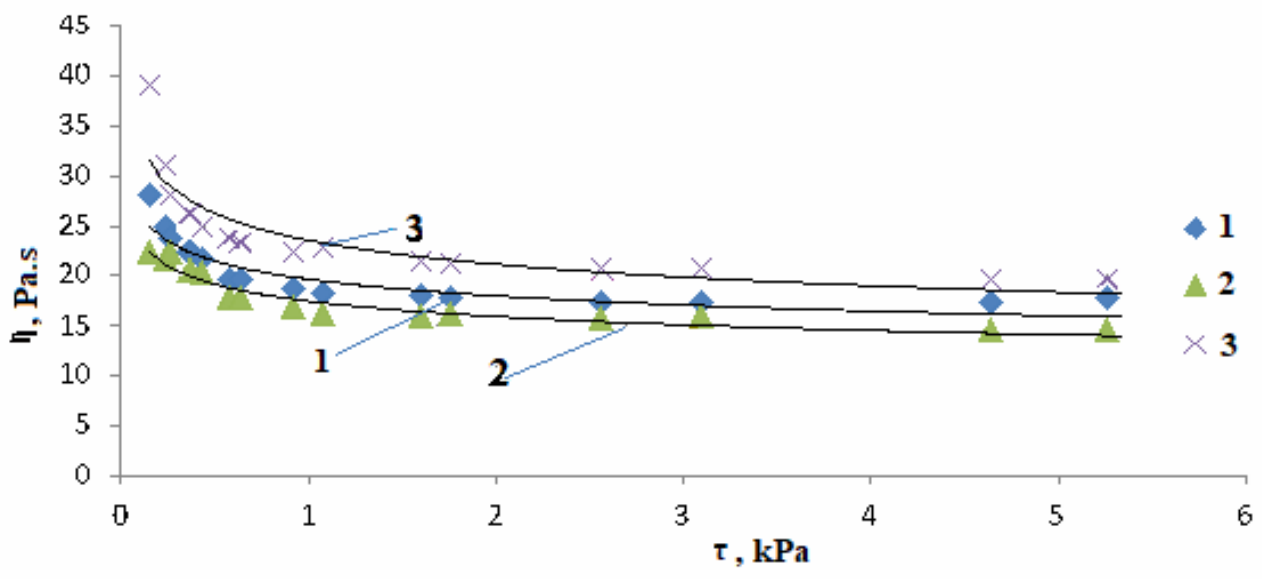

Fig. 2. The viscosity (323 K) of paste-like compositions based on SNBR-N with $0.5 \mathrm{wt} . \%$ of surface-active compound (POPG) and 3 wt. $\%$ of BIO-5A plasticizer with different degree of filling: $1-(70$ wt. $\%$ of $\mathrm{KCl}$ modified by 2 wt. $\%$ PGO-7+15 wt. $\%$

of $\mathrm{Al}$ ), 2 - (70 wt.\% of $\mathrm{KCl}$ modified by 2 wt.\% PGO- $6+15$ wt. $\%$ of $\mathrm{Al}), 3-(75$ wt. $\%$ of $\mathrm{KCl}$ modified by 2 wt. $\%$ PGO-6+15 wt.\% of $\mathrm{Al})$

Thus, for plasticizers close to diene rubber, Fig. 2. which contain alkane and alkene fragments (the residues of higher carboxylic acids), there is a reduction in viscosity by a factor of 3 . The said composition has remained stable for six months while being stored at $298 \mathrm{~K}$. To complete the research and obtain low-viscosity compositions with maximum degree of filling up to $90 \mathrm{wt} \%$, the surface of $\mathrm{KCl}$ was modified by 2 wt.\% PGO-4 additive and used in the composition of a BIO-5A binder in quantity of $3 \mathrm{wt} . \%$ of the total mass of the composition. The results of the viscosity measurements are shown in

In addition to measuring the viscosity of the obtained maximum-filling paste-like composition containing a $\mathrm{BIO}-5 \mathrm{~A}$ plasticizer, an evaluation of its stability during a prolonged exposure (6 months) at room temperature $(298 \mathrm{~K})$ was made. There are no signs of loss of homogeneity and fluidity of the composition due to stratification by the decomposition of the plasticizer or the disruption of the continuity. At the same time, the composition with an elevated content of dioctyl phthalate (DOP) (6-9 wt.\%) even at a lower degree of filling 
(85 wt.\%) became dispersed immediately at room temperature [9]. It can be assumed that the use of PGO-6 and PGO-7 additives as a surface modifier of $\mathrm{KCl}$ contributes to an increase in the adhesive interaction of non-polar rubber and polar filler.

A comparative assessment of the rheological properties of the compositions under study was carried out by calculating the activation energy of their viscous flow (E) according to the method described in ref. [15] for the temperature range of 293 to $323 \mathrm{~K}$. According to data shown in Table 4, the most effective composition with a degree of filling of $90 \mathrm{wt} . \%$ has practically the same value of $\mathrm{E}$ as pure SNBR-N.

Density is another important characteristic of a fuel compound. The density of the investigated composition was calculated (by densities of each compound component) and experimentally determined. The value of experimentally measured density of highly-filled (90 wt.\%) composition is $1648 \mathrm{~kg} \mathrm{~m}^{-3}$, whereas the calculated values is $1683 \mathrm{~kg} \mathrm{~m}^{-3}$, which shows good coincidence of the obtained results.

A proof of the higher efficiency of the BIO-5A plasticizer against DOP plasticizer is provided by the obtained temperature dependences of viscosity of paste-like compositions (Figs. 3 and 4).

The comparison confirms the higher efficiency of the use of the BIO-5A plasticizer, which provides a greater reduction in the viscosity of the composition filled to $90 \mathrm{wt} . \%$, as compared with the viscosity of the composition based on DOP and filled to $85 \mathrm{wt} . \%$.

According to obtained results, the use of PGO-6 surface modifier and BIO-5A plasticizer as alternative to classic DOP allows producing a stable highly-filled (90 wt.\%) composition with low viscosity. The developed material fully satisfies all requirements for the paste-like fuels.

\section{Conclusions}

1 The correlation between viscosity and shear stress in temperature range of 293 to $323 \mathrm{~K}$ was considered for the model composition of paste-like fuel consisting of non-functionalized oligomeric rubber and highly dispersed fillers $(\mathrm{KCl}$ instead of real oxidizer and $\mathrm{Al}$ ) with a maximum degree of filling and zero oxygen balance.

2. The FAME mixtures of sebacic, palmitic and oleic acids as plasticizers in paste-like model

Table 4

The activation energy of viscous flow of the compositions based on SNBR-N*

\begin{tabular}{|c|c|c|c|c|c|}
\hline \multirow[b]{2}{*}{$\begin{array}{c}\text { Temperature } \\
\text { range, } \mathrm{K}\end{array}$} & \multicolumn{5}{|c|}{ Activation energy of viscous flow of the compositions based on SNBR-N (wt.\%), $\mathrm{kJ} \mathrm{mol}^{-1}$} \\
\hline & SNBR-N & $\begin{array}{c}\text { SNBR-N } 20 \\
\mathrm{KCl} 80\end{array}$ & $\begin{array}{c}\text { SNBR-N } 18 \\
\mathrm{KCl}_{\mathrm{m}} 81.5 \\
\text { POPG } 0.5\end{array}$ & $\begin{array}{c}\text { SNBR-N } 10 \\
\mathrm{KCl}_{\mathrm{m}} 71.5 \\
\text { Al } 15 \\
\text { POPG } 0.5 \\
\text { DOP } 3\end{array}$ & $\begin{array}{c}\text { SNBR-N } 5 \\
\mathrm{KCl}_{\mathrm{m}} 76.5 \\
\text { Al } 15 \\
\text { POPG } 0.5 \\
\text { BIO-5A } 3\end{array}$ \\
\hline $293-303$ & 23.8 & 92.7 & 35.1 & 42.3 & 27.2 \\
\hline $303-313$ & 17.7 & 78.2 & 30.6 & 33.4 & 19.0 \\
\hline $313-323$ & 11.3 & 63.5 & 19.2 & 26.7 & 14.3 \\
\hline
\end{tabular}

*Note: $\mathrm{KCl}_{\mathrm{m}}$ stands for $\mathrm{KCl}$ which was surface-modified by PGO (2 wt.\%).

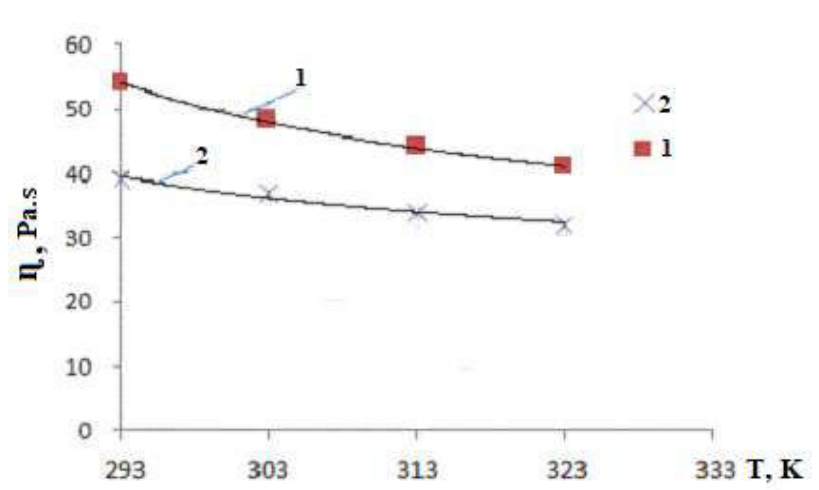

Fig. 3. The temperature dependence of the viscosity of pastelike composition (degree of filling $85 \mathrm{wt} . \%$ ) plasticized by DOP at the following shear stress: $1-\tau=6 \mathrm{kPa} ; 2-\tau=10 \mathrm{kPa}$

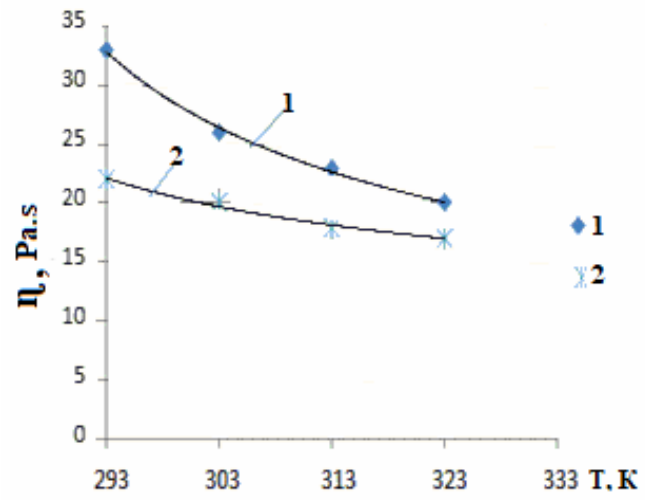

Fig. 4. The temperature dependence of the viscosity of pastelike composition (filling degree $90 \mathrm{wt} . \%$ ) plasticized by BIO$5 \mathrm{~A}$ at the following shear stress: $1-\tau=6 \mathrm{kPa} ; 2-\tau=10 \mathrm{kPa}$ 
fuel composition are more efficient in terms of influence on rheological properties and possible degree of filling of the composition than those considered earlier and containing dioctyl phthalate.

3. It was established that the use of surfaceactive compounds jointly with the modification of filler by the products of polyethyleneterephthalate alcoholysis and application of plasticizers close in their nature to oligomeric rubber makes it possible to increase the degree of filling of the model fuel composition to the limiting value of $90 \mathrm{wt} . \%$. The prepared composition is stable and homogeneous without plasticizer exudation on the surface.

\section{REFERENCES}

1. Recent advances in research on solid rocket propulsion / Fabignon Y., Anthoine J., Davidenko D., Devillers R., Dupays J., Gueyffier D., et al. // AerospaceLAB Journal. - 2016. - No. 11. - Art. No. AL11-13.

2. Bondarenko S.G., Horolski P.G., Adamchik L.V. To an estimation of power weight efficiency of rocket engines on pastelike fuel with deep choking // Aviatsionno-Kosmicheskaya Tekhnika i Tekhnologiya. - 2008. - Vol.7. - P.148-150.

3. Ivanchenko A.M. Special features of rocket propulsion on paste-like fuel // Kosmichna Nauka i Tekhnologiya. - 1999. - Vol.5. - No. 4. - P.3-10.

4. Rocket propulsion elements / Eds. G.P. Sutton, O. Biblarz. -8 th ed. - Hoboken, New Jersey: John Wiley \& Sons, Inc. 2010. -785 p.

5. Ivanchenko A.N., Bondarenko S.G. Fine-tuning the condition of throttling rocket propulsion installations on unitary paste-like propellant // Problemy Vysokotemperaturnoi Tekhniki. - 2007. - Vol.5. - P.40-50.

6. Tadros T.F. Rheology of dispersions: principles and applications. - Wiley-VCH, 2010.

7. Brockel U., Meier W., Wagner G. Product design and engineering: formulation of gels and pastes. - Weinheim: John Wiley \& Sons, Inc. - 2013.

8. Experimental and numerical research rheological descriptions of paste-like propellant compositions / Eliseev V., Bondarenko S., Kurochkin A., Mayorskaya T., et al. // Zaporozhye, Vestnik Dvigatelestroeniya. - 2012. - No. 1. P.26-30.

9. The effect of pre-encapsulating dispersed filler on the rheological properties of highly filled paste-like compositions based on oligomeric rubber / Surovtsev A.B., Pajos H.G., Dyachenko M.P., Mandziuk I.A. // Voprosy Khimii i Khimicheskoi Tekhnologii. - 2019. - No. 5. - P.143-152.

10. Liquid hydrocarbon rubbers / Mogilevich M.M., Turov B.S., Morozov Yu.L, Ustavshikov B.F. // Moscow: Khimiya, 1983. - 200 p.
11. Influence of the nature of surface-active substances on rheology of high-filled paste-like compositions on a base on liquid diene rubber and disperse filler / Surovtsev A., Kovalenko K., Kuzmenko N., Bondarenko S. // Bull. Dnipropetrovsk Univ. Ser. Chem. - 2014. - Vol.22. - No. 1. - P.76-81.

12. Mandzuk I.A., Vanishina O.V. Glycerolization of PET waste. Features of kinetics // Khimichna Promyslovist' Ukrainy. - 2006. - Vol.1. - P.42-46.

13. O'Brien $R$. Fats and oils. Production, composition and properties, application. - St. Petersburg: Professiya, 2007. - 752 p.

14. Modification of alkyd paints and varnishes by methyl esters of fatty acids. Part 1. Rheological properties / Chervakov O.V., Suvorova Yu.A., Kuzminsky V.Yu., Gerasymenko K.O., et al. // Voprosy Khimii i Khimicheskoi Tekhnologii. - 2013. - No. 3. P.43-47.

15. Suberlyak O.V., Bashtannik P.I. Technology of the processing of polymers and composite materials. - Lviv: Rast-7, 2007. -375 p.

Received 28.02.2021

\section{ДОСЛІДЖЕННЯ РЕОЛОГІЧНИХ ВЛАСТИВОСТЕЙ ВИСОКОНАПОВНЕНОЇ ПАСТОПОДІБНОЇ ПАЛИВНОЇ КОМПОЗИЦІЇ НА ОСНОВІ ОЛІГОМЕРНОГО КАУЧУКУ І ДИСПЕРСНИХ НАПОВНЮВАЧІВ}

\section{О.Б. Суровцев, І.А. Мандзюк, Д.О. Черваков, М.Ф. Сеферова, О.В. Черваков}

Описано результати створення модельних пастоподібних паливних композицій з високим ступенем наповнення (до 90 мас.\%) та дослідження їх реологічних властивостей. Розроблена композиція містить такі компоненти: полімерну матрицю (бутадієновий каучук типу СКДН-Н) і суміш неорганічних наповнювачів - попередньо поверхнево-модифікованого високодисперсного калій хлориду (мікрокапсульований з використанням олігомерних продуктів гліцеролізу поліетилентерефталату) та високодисперсного алюмінієвого порошку. Як додаткові компоненти використано поверхнево-активну сполуку (олігомерний поліоксипропіленгліколь) та пластифікатори різної природи, які вводили для збільшення ступеня наповнення одержаних пастоподібних композицій при збереженні низького рівня їх в'язкості. Динамічну в'язкість композицій оцінювали в діапазоні напружень зсуву від 1 до 30 кПа та температур від 293 до 323 К на поворотному віскозиметрі (система конус-площина). Встановлено, що в'язкість високонаповненої (до 90 мас.\%) композиції з пластифікатором, який є сумішшю насичених i ненасичених метилових естерів жирних кислот, знаходиться на тому ж рівні, що і для вихідного олігомерного бутадієнового каучуку типу СКДН-Н.

Ключові слова: високонаповнена пастоподібна паливна композиція, реологічні властивості, дисперсні наповнювачі, олігомерний каучук, поверхнева модифікація, поверхневоактивна речовина, пластифікатор. 


\section{STUDY OF THE RHEOLOGICAL PROPERTIES OF THE HIGHLY-FILLED PASTE-LIKE FUEL COMPOSITION BASED ON OLIGOMERIC RUBBER AND DISPERSED FILLERS}

\author{
A.B. Surovtsev ${ }^{a,}{ }^{*}$, I.A. Mandzyuk ${ }^{b}$, D.O. Chervakov ${ }^{c}$, \\ M.F. Seferova ${ }^{d}$, O.V. Chervakov ${ }^{c}$
}

a Oles Honchar Dnipro National University, Dnipro, Ukraine

b Khmelnytskyi National University, Khmelnytskyi, Ukraine

c Ukrainian State University of Chemical Technology, Dnipro, Ukraine

d Dnipro State Medical University, Dnipro, Ukraine

*e-mail: absurov55@gmail.com

We present the results of creation of paste-like fuel compositions with a high degree of filling (up to $90 \mathrm{wt} . \%$ ) and investigation of their rheological properties. The developed composition contained the following components: a polymer matrix (type SNBR-N butadiene rubber) and a mixture of inorganic fillers (preliminarily surface-modified highly disperse potassium chloride, that was microencapsulated by using oligomeric products of polyehtyleneterepthalate glycerolize, and highly dispersed aluminum powder. A surface-active compound (oligomeric polioxypropylene glycol) and plasticizers of different natures were used as additional components, which were introduced in order to increase the degree of filling of the resulting paste-like compositions while maintaining a low level of their viscosity. The dynamic viscosity of the compositions was evaluated in the range of the shear stresses of 1 to $30 \mathrm{kPa}$ and the temperatures of 293 to $323 \mathrm{~K}$ by using a rotary viscometer (coneplane system). The viscosity of the composition which is a mixture of saturated and unsaturated methyl ester fatty acids at the maximum degree of filling (90 wt.\%) was at the level of viscosity of the individual binder.

Keywords: highly filled paste-like fuel composition; rheological properties; dispersed filler; oligomeric rubber; surface modification; surface-active compound; plasticizer.

\section{REFERENCES}

1. Fabignon Y, Anthoine J, Davidenko D, Devillers R, Dupays J, Gueyffier D, et al. Recent advances in research on solid rocket propulsion. AerospaceLAB J. 2016; (11): AL11-13. doi: 10.12762/2016.AL11-13.

2. Bondarenko SG, Horolski PG, Adamchik LV. K otsenke energomassovoi effektivnosti raketnykh dvigatelei na pastoobraznom toplive s glubokim drosselirovaniem [To an estimation of power weight efficiency of rocket engines on pastelike fuel with deep choking]. Aviatsionno-Kosmicheskaya Tekhnika i Tekhnologiya. 2008; 7: 148-150. (in Russian).

3. Ivanchenko AM. Osobennosti raketnoi tyagi na pastoobraznom toplive [Special features of rocket propulsion on paste-like fuel]. Kosmichna Nauka i Tekhnologiya. 1999; 5(4): 3-10. (in Russian).

4. Rocket propulsion elements. 8th edition. Sutton GP, Biblarz O, editors. Hoboken, New Jersey: John Wiley \& Sons, Inc.; 2010. 785 p.
5. Ivanchenko AN, Bondarenko SG. Otrabotka uslovii drosselirovaniya reaktivnykh dvigatelnykh ustanovok na unitarnom pastoobraznom toplive [Fine-tuning the condition of throttling rocket propulsion installations on unitary paste-like propellant]. Problemy Vysokotemperaturnoi Tekhniki. 2007; 5: 40-50. (in Russian).

6. Tadros TF. Rheology of dispersions: principles and applications. Wiley-VCH, 2010.

7. Product design and engineering: formulation of gels and pastes. Brockel U, Meier W, Wagner G, editors. John Wiley \& Sons, Inc.; 2013.

8. Eliseev V, Bondarenko S, Kurochkin A, Mayorskaya T. Eksperimentalnye i chislennye isledovaniya reologicheskikh kharakteristik pastoobraznykh toplivnykh kompozitsii [Experimental and numerical research on the rheological parameters of paste-like propellant compositions]. Vestnik Dvigatelestroeniya. 2012; (1): 26-30. (in Russian).

9. Surovtsev AB, Paios AG, Dyachenko MP, Mandzyuk IA. The effect of pre-encapsulating dispersed filler on the rheological properties of highly filled paste-like compositions based on oligomeric rubber. Voprosy Khimii i Khimicheskoi Tekhnologii. 2019; (5): $143-152$.

doi: 10.32434/0321-4095-2019-126-5-143-152.

10. Mogilevich MM, Turov BS, Morozov YuL, Ustavshikov BF. Zhidkie uglevodorodnye kauchyki [Liquid hydrocarbon rubbers]. Moscow: Khimiya; 1983. 200 p. (in Russian).

11. Surovtcev A, Kovalenko K, Kuzmenko N, Bondarenko S. Vliyanie prirody poverchnostno-aktivnykh veshchestv na reologiyu vysokonapolnennykh pastoobraznykh kompozitsii na osnove zhidkogo dienovogo kauchuka i dispersnogo napolnitelya [Influence of the nature of surface-active substances on rheology of high-filled paste-like compositions on a base on liquid diene rubber and disperse filler]. Bull Dnipropetrovsk Univ Ser Chem. 2014; 22(1): 76-81. (in Russian). doi: 10.15421/081415.

12. Mandzuk IA, Vanishina OV. Glitserizatsiya vidkhodiv PET. Osoblyvosti kinetyky [Glycerolization of PET waste. Features of kinetics]. Khimichna Promyslovist' Ukrainy. 2006; 1: 42-46. (in Ukrainian).

13. O’Brien R. Zhiry i masla. Proizvodstvo, sostav i svoistva, primenenie [Fats and oils. Production, composition, properties, and application]. St. Petersburg: Professiya; 2007. 752 p. (in Russian).

14. Chervakov OV, Suvorova YuA, Kuzminsky VYu, Gerasymenko KO. Modifikatsiya alkidnykh lakov i krasok metilovymi efirami zhirnych kislot. Chast' 1. Reologicheskie svoistva [Modification of alkyd paints and varnishes by methyl esters of fatty acids. Part 1. Rheological properties]. Voprosy Khimii i Khimicheskoi Tekhnologii. 2013; (3): 43-47. (in Russian).

15. Suberlyak OV, Bashtannik PI. Tekhnologiya pererobki polimeriv $i$ kompozytsiynykh materialiv [Technology of the processing of polymers and composite materials]. Lviv: Rast-7; 2007. 375 p. (in Ukrainian). 